\title{
Mathematical modeling of dehydration resistance of pericarp tissues and endosperm in fruits of arabic coffee
}

\author{
Camila de Almeida Dias ${ }^{1}$ (D), Ednilton Tavares de Andrade ${ }^{1}$ (D), Isabella Àvila Lemos ${ }^{1}$ (D), Flávio Meira Borém ${ }^{1}$ (D), \\ Diogo Nogueira Westerich ${ }^{1}$ (D), Ana Claudia Almeida da Silva ${ }^{1}$ (D)
}

${ }^{1}$ Universidade Federal de Lavras/UFLA, Departamento de Engenharia Agrícola/DEA, Cx. P. 3037 - 37.200-900 - Lavras - MG Lavras, MG, Brasil

Contact authors: camila.almeidadias@gmail.com, ednilton@ufla.br, isa_lemosti@hotmail.com, flavioborem@ufla.br, diogowesterich@yahoo.com.br, anaclaudia.alsi@hotmail.com Received in November 11, 2019 and approved in March 10, 2020

\begin{abstract}
Coffee represents an important source of income for producers and for the Brazilian economy, being the second product in the country's agricultural exports. Unlike other agricultural products, freshly harvested coffee has a high fruit water content, approximately $60 \%$ (dry base). It is fundamental to optimize the drying process for cost reduction and quality maintenance, making it necessary to understand the interdependence relation of the tissues of the pericarp and the coffee endosperm during the dehydration of the fruit. The objective of this work was to elaborate a drying model for the constituent parts of coffee fruits evaluating the resistance of each of the pericarp tissues and endosperm. The experiment was set up in a $4 \times 6$ factorial scheme $(4$ relative humidity of the drying air and natural, pulped natural coffee, pericarp tissues and endosperm: 1 - natural coffee and 2 - pulped natural coffee, 3 - exocarp + a portion of mesocarp, 4 - mesocarp, 5 - endocarp, 6 - endosperm]) in a completely randomized design with four replicates. The results were analyzed through analysis of variance and regression, using the statistical software STATISTICA 5.0 ${ }^{\circ}$. The resistance to water outflow, regardless of the processing or the fruit part of the coffee, is greater when the coffee is dried with the lowest relative humidity. The natural coffee was the treatment that presented greater resistance, while the lower resistance was presented by the exocarp + a portion of mesocarp.
\end{abstract}

Key words: Drying; Coffea arabica L.; Relative humidity.

\section{INTRODUCTION}

Coffee is a very important product in global agribusiness as it is one of the most consumed beverages in the world (Toci et al., 2013). The 2019 harvest foresees, in almost all coffee producing regions of the country, the influence (especially on arabica coffee) of negative biennials, estimating production between 50.48 million and 54.48 million bags benefited (Companhia Nacional de Abastecimento - CONAB, 2019).

The country has high production estimates annually, however, with regard to drying technologies or methodologies, there is still a large deficit, which makes drying a crucial step in the coffee production.

Every year new technologies in the postharvest of coffee are brought to market, but the behavior of each intrinsic part of coffee during drying and how this interaction and interdependence occurs is not yet known. The resistance imposed by the pericarp and endosperm tissues that make up the coffee fruit increases the drying time and, consequently, the energy expenditure (Dias et al., 2020).

The study of the morphology and anatomy of the coffee fruit, allied to the chemical components that the coffee has, is basic. Deepening knowledge helps in making decisions during product processing, how to choose the best drying method, time and even help define the best storage method.

The fruit of coffee is classified as a drupe containing two locus and two seeds/beans (endosperm) and may occasionally contain three or more; it's also composed of the exocarp (skin), mesocarp (mucilage) and endocarp (parchment) (Borém; Garcia-Salva; Silva, 2014a).

Each of these coffee pericarp tissues and endosperm has differences in their chemical composition, as well as moisture content. Thus, in the case of coffee fruits, which are usually harvested with moisture content between 30 and $65 \%$, depending on the ripening stage, drying is fundamental and most used to preserve the product, being this the stage of great importance from the economic point of view and the maintenance of product quality (Borém; Reinato; Andrade, 2008).

During drying, the reduction in moisture content occurs because a water vapor pressure difference between the surface of the product to be dried and the air surrounding it. For drying to occur, it is necessary that the partial pressure of water vapor on the surface must be greater than the partial pressure of water vapor in the drying air (Pabis; Jayas; Cenkowsk, 1998).

To develop models to evaluate the influence of each anatomical component of coffee fruit to dehydration, it's necessary to verify the resistance of each of these tissues and the endosperm.

It's generally accepted that on drying, water diffusion and Fick's law control changes in water content and successfully describe drying curves (Resio; Aguerre; Suarez, 2005).

Becker and Sallans (1957) postulated two mechanisms of water migration during dehydration of wheat grains. At moisture content levels above $14 \%$ (dry base) water migrates 
by porous wheat grain structure as a viscous flow with the pressure gradient as the driving force for diffusion. As the moisture content decreases, the water doesn't completely fill the pores, but forms a film that covers the inner surfaces.

In addition to the water concentration gradient and vapor pressure gradient, other gradients, such as spreading pressure gradient, were assumed to be the driving force of the drying process (Babbitt, 1950). The choice of the driving force is important from a physical point of view, because careful consideration of the physical aspects can contribute to the development of more precise relationships between the diffusion coefficient and the moisture content.

The diffusion coefficient (DEF) describes the water outflow velocity of the product exposed to the drying process and involves the effects of all phenomena that may interfere with water migration, then its value is measured by adjusting experimental values. As diffusivity may change, as it changes with drying conditions (temperature and air velocity), it is not intrinsic to the material. Therefore, it is conventionally called effective diffusivity (Oliveira; Oliveira; Park, 2006).

Thus, as the diffusion coefficient describes the water outflow velocity of the product, it can then be used as a parameter for the development of models that describe the resistance imposed by each anatomical component to water outflow of coffee fruit.

The resistance to dehydration of the pericarp tissues and endosperm will depend on each of these factors and the relationship between them, along with anatomical differences and chemical components.

Thus, the objective of this study was to evaluate the resistance imposed by the pericarp tissue and the endosperm that make up the coffee fruit, observing the influence of each anatomical component on dehydration, developing a mathematical model that describes this resistance to dehydration.

\section{MATERIAL AND METHODS}

The present work was developed at the Agricultural Product Processing Laboratory at the Agricultural Engineering Department of the Federal University of Lavras (UFLA), Lavras, MG. To conduct the experiment, cherry coffee (Coffea arabica L. cv. Catuaí Vermelho) fruits were harvested manually in a field located in Ingaí - MG. After harvesting, the fruits were separated in water by density difference, it employs flotation to separate the more dense unripe and ripe fruit from the less dense fruit, know as floaters (Borém; Isquierdo; Taveira, 2014b).

The harvested fruits were also processed to obtain the coffee parts: exocarp (skin + a portion of mesocarp), mesocarp (mucilage), endocarp (parchment) and endosperm (beans), so that individual drying was performed.
The skin of coffee fruits was removed manually in order to avoid possible damage to the exocarp, thus obtaining the exocarp + a portion of the mesocarp. For removal of most of the mesocarp (mucilage), which is adhered to the exocarp, the exocarp was washed in running water and then sieved so that the surface water was drained.

The mesocarp was obtained from the passage of the pulped natural coffees by a centrifugal machine. At this stage, no water was used to avoid interference with the amount of mesocarp obtained. Soon after, the mesocarp was passed through a filter (plastic sieve) removing the solid impurities that are retained there. The mesocarp was taken in petri dishes for drying.

The endocarp was removed manually the beans with tweezers. The exocarp and mesocarp had been previously removed. However, for drying, only the endocarps that were removed and intact were used, without damage to its structure.

After removal of the endocarp, it was possible to obtain the endosperm. Thus, the endocarp and endosperm were dried in polyester bags for drying.

The coffee fruits were submitted to drying in a system composed of air conditioning coupled to a fixed layer drier (SCAL) (Fortes et al., 2006) with air flow of $20 \mathrm{~m}^{3} \cdot \mathrm{min}^{1} \cdot \mathrm{m}^{-2}$, air temperature of $40{ }^{\circ} \mathrm{C}$ (avoiding thermal damage to the product) and relative humidity values of $10 \%, 17.5 \% ; 25 \%$ and $32.5 \%$. The equipment called SCAL allows precise control of flow, temperature $(\mathrm{T})$ and relative humidity $(\mathrm{RH})$ of drying air. To obtain the lowest dew point temperatures and, consequently, the lowest relative humidity, before SCAL, the air was preconditioned by a refrigeration system composed of three air conditioning units.

The experiment was set up in a $4 \times 6$ factorial scheme ( 4 relative humidity of the drying air and natural, pulped natural coffee, pericarp tissues and endosperm [1 - natural coffee and 2 - pulped natural coffee, 3 - exocarp + a portion of mesocarp, 4 - mesocarp, 5 - endocarp, 6 - endosperm]) in a completely randomized design with four replications. The results were analyzed by analysis of variance and regression using the statistical software STATISTIC 5.0 ${ }^{\circledR}$.

During drying, weighings were performed with a time interval of 10, 20, 30, 60 and 120 minutes. Time intervals of 10 and 20 minutes were used for the exocarp + a portion of the mesocarp, mesocarp and endocarp, given that these tissues reached constant weight rapidly, thus after three consecutive weighings showing the same value, with a difference of $0,01 \mathrm{~g}$, drying was finalized.

For endosperm, natural and pulped natural coffee, the time intervals were 30,60 and 120 minutes until they reached the ideal storage moisture content around 11\% (dry base).

The resistance system of the intrinsic parts of coffee fruit to water outflow was considered as series resistance as follows (Figure 1): 


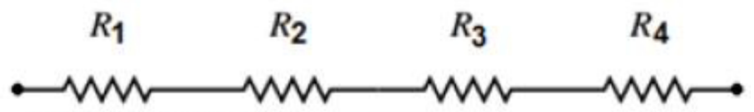

Figure 1: Watershed resistance distribution scheme for the various intrinsic parts of coffee fruit.

Equation 1 presents the sum of the resistance of the coffee pericarp tissues and endosperm.

$R_{S}=R 1+R 2+R 3+R 4$

In which:

$\mathrm{R}_{\mathrm{s}}$ : Total resistance.

$\mathrm{R} 1$ : Exocarp + a portion of mesocarp.

R2: Mesocarp.

R3: Endocarp.

R4: Endosperm.

For the drying modeling of each part of the coffee fruit, an experimentally determined correction coefficient was considered for each part in order to correct the error of the fact that the parts were already separated. It can be stated that the total resistance was established by following the expression (Equation 2) below:

$$
\mathrm{R}_{\mathrm{s}}=\left(\frac{1}{\mathrm{R} 1} * \mathrm{D} 1\right)+\left(\frac{1}{\mathrm{R} 2} * \mathrm{D} 2\right)+\left(\frac{1}{\mathrm{R} 3} * \mathrm{D} 3\right)+\left(\frac{1}{\mathrm{R} 4} * \mathrm{D} 4\right)
$$

In which:

$\mathrm{R}_{\mathrm{s}}$ : Total resistance.

$\mathrm{R} 1$ : Exocarp + a portion of mescarp.

R2: Mesocarp.

R3: Endocarp.

R4: Endosperm.

D1: Coefficient of correction of the resistance imposed by water removal by the exocarp + a portion of mesocarp.

D2: Coefficient of correction of the resistance imposed by water removal by the mesocarp.

D3: Coefficient of correction of the resistance imposed by water removal by the endocarp.

D4: Coefficient of correction of the resistance imposed by water removal by the endosperm.

For the development of the resistance model used, it was considered that the resistance of each anatomical component depends on the value of the effective diffusion coefficient.

According to Resio, Aguerre and Suarez (2005), the equation develops, assuming that the driving force for the diffusion of bound water is the spreading pressure, $\pi$; for isothermal conditions, it may be related to surface free energy by the following expression (Smith; Van Ness; Abbott, 1997) (Equation 3):

$$
d \pi=\sigma R T d\left(\ln a_{w}\right)
$$

In which $\sigma$ is the surface water concentration, $R$ is the gas constant, $T$ is the absolute temperature and $\mathrm{a}_{\mathrm{w}}$ water activity. Water surface concentration and water content are related by the equation (Equation 4):

$\sigma=\frac{m}{M \gamma}$

In which $m$ is the moisture content, $M$ is the molecular weight of water and $\gamma$ is the specific surface area of the solid. Substituting equation (4) for equation (3) and integrating results into (Equation 5):

$$
\pi=\frac{R T}{M \gamma} \int_{0}^{a_{w}} m d\left(\ln a_{w}\right)
$$

The mass flow rate of water by spreading pressure is defined as (Babbitt, 1950) (Equation 6):

$$
J=-\eta \rho m \frac{d \pi}{d r}
$$

In which $\eta$ is a resistance coefficient, $\rho$ is the solid density, $m$ is the water content and $d \pi / d r$ is the spreading pressure gradient.

The differentiation equation (5) and the substitution of the result in equation (6) result in (Equation 7):

$J=-\eta \rho \frac{R T}{M \gamma} \frac{m^{2}}{a_{w}} \frac{d a_{w}}{d m} \frac{d m}{d r}$

The differential continuity equation for water migration in a spherically porous solid is (Equation 8):

$$
\frac{\partial \rho_{A}}{\partial t}+\frac{1}{r^{2}} \frac{\partial}{\partial t}\left(r^{2} J\right)=0
$$

In which $\rho_{A}$ is the concentration of water per unit volume of solid. If the expression of $J$ given by Equation (7) is replaced by Equation (8), assuming that $\rho_{A}=m_{\rho}$, the equation result in (Equation 9):

$$
\frac{\partial m}{\partial t}=\frac{1}{r^{2}} \frac{\partial}{\partial r}\left\{r^{2} D(m) \frac{\partial m}{\partial r}\right\}
$$

$D(m)$ represents the diffusion coefficient dependence on moisture content, given by the expression (Equation 10):

$$
D(m)=\frac{\eta R T}{M \gamma} \frac{m^{2}}{a_{w}} \frac{d a_{w}}{d m}
$$

From this equation, the diffusion coefficient can be obtained by evaluating $\mathrm{a}_{\mathrm{w}}$ and $d a_{w} / d m$ from the isothermal equation 
GAB. The three-parameter GAB model can be written as (Schär; Ruëgg, 1985) (Equation 11):

$\frac{m}{m_{m}}=\frac{C k a_{w}}{\left(1-k a_{w}\right)\left(1-k a_{w}+C k a_{w}\right)}$

In which $m_{m}$ is the monolayer moisture content and $\mathrm{C}$ and $\mathrm{k}$ are the parameters of the GAB equation. Operating with Equation (11) and replacing the results with Equation (10), we have the expression (Equation 12):

$D(m)=\frac{\eta \cdot R \cdot T}{M \cdot \gamma} \cdot\left(\frac{C \cdot m_{m} \cdot k \cdot a_{w}}{1+(C-1) \cdot k^{2} \cdot a_{w}^{2}}\right)$

To calculate the diffusion coefficient that was used as a parameter, for determination, the model was used (Costa et al., 2011) (Equation 13):

$R-U=\frac{X^{*}-X_{e}^{*}}{X_{i}^{*}-X_{e}^{*}}=\frac{6}{\pi^{2}} \sum_{n=1}^{\infty} \frac{1}{n^{2}} \exp \left(-\frac{n^{2} \pi^{2} D_{e f} t}{9}\left(\frac{3}{R}\right)^{2}\right)$

In which $R U$ is the moisture ratio, $D_{e f}$ is the effective diffusion coefficient, $n$ is the number of terms, in which case 8 terms are approximated, $R$ is the equivalent radius of the sphere and $t$ is the time.

The coffee fruit, considered as spheroid, determines that the specific surface area of the product is calculated as (Equation 14):

$\gamma=4 \pi \cdot r^{2}$

Thus, Equation 14 was used to determine the specific area of natural and pulped natural coffee, and endosperm.

To determine the specific area of the exocarp + a portion of the mesocarp and endosperm, Equation 15 was used and for the mesocarp, Equation 16 was used:

$\gamma=\pi \cdot r^{2}+\pi \cdot(r-x)^{2}$

$\gamma=\frac{\pi \cdot D(m)^{2}}{4}$

D (m): Diffusion coefficient $\left(\mathrm{m}^{2} \cdot \mathrm{s}^{-1}\right)$.

$\eta$ : Coefficient of resistance $\left(\mathrm{m}^{2} . \mathrm{s} . \mathrm{kg}^{-1}\right)$

$\mathrm{R}$ : Universal gas constant $\left(8,3144621 \mathrm{~J} \cdot \mathrm{K}^{-1} \cdot \mathrm{mol}^{-1}\right)$.

$\mathrm{T}$ : Absolute temperature $(\mathrm{K})$.

$\mathrm{M}$ : Molecular weight of water $\left(\mathrm{kg} \cdot \mathrm{mol}^{-1}\right)$.

$\gamma$ : Specific area of solid $\left(\mathrm{m}^{2}\right)$.

$\mathrm{a}_{\mathrm{w}}$ : Water activity (dimensionless).

$\mathrm{m}_{\mathrm{m}}$ : Initial moisture content (d.b.).

$\mathrm{C}, \mathrm{k}$ : GAB equation parameters (dimensionless).
R: Sphere radius $\left(\mathrm{m}^{2}\right)$.

D: Petri dish diameter in mesocarp drying $\left(\mathrm{m}^{2}\right)$.

$\mathrm{x}$ : Average thickness (exocarp or endosperm) $\left(\mathrm{m}^{2}\right)$.

In which:

To perform the mathematical modeling of the data, in order to correct the fact that the parts were already separated, it was necessary to create correction coefficients for each part of the coffee fruit. Considering that the total resistance is equivalent to the resistance of natural coffee, the proposed model for the water resistance was described as (Equation 17):

$\eta_{t}=A \cdot X_{c p} \cdot \eta_{c p}+B \cdot X_{m} \eta_{m}+C \cdot X_{p} \cdot \eta_{p}+D \cdot X_{g} n_{g}$

In which:

$\eta_{t}$ : Total resistance coefficient $\left(\mathrm{m}^{2} . \mathrm{s} . \mathrm{kg}^{-1}\right)$.

$\eta_{c p}$ : Exocarp + a portion of exocarp resistance coefficient $\left(\mathrm{m}^{2} . \mathrm{s} \cdot \mathrm{kg}^{-1}\right)$.

$\eta_{m}$ : Coefficient of resistance of the mesocarp $\left(\mathrm{m}^{2} . \mathrm{s} \cdot \mathrm{kg}^{-1}\right)$.

$\eta_{p}$ : Endocarp resistance coefficient $\left(\mathrm{m}^{2} . \mathrm{s} . \mathrm{kg}^{-1}\right)$.

$\eta_{g}$ : Endosperm resistance coefficient $\left(\mathrm{m}^{2} . \mathrm{s} \cdot \mathrm{kg}^{-1}\right)$.

$\mathrm{X}_{\mathrm{cp}}$ : Influence of exocarp average thickness on water outflow (decimal - dimensionless).

$\mathrm{X}_{\mathrm{m}}$ : Influence of mesocarp average thickness on water outflow (decimal - dimensionless).

$\mathrm{X}_{\mathrm{p}}$ : Influence of endocarp average thickness on water outflow (decimal - dimensionless).

$\mathrm{X}_{\mathrm{g}}$ : Influence of endosperm average thickness on water outflow (decimal - dimensionless).

A: Correction coefficients for the exocarp + a portion of mesocarp (dimensionless).

B: Correction coefficients for the mesocarp(dimensionless).

$\mathrm{C}$ : Correction coefficients for the endocarp (dimensionless).

D: Correction coefficients for the endosperm (dimensionless).

The influence of average thickness on water outflow was calculated taking into account that the influence of the thickness of natural coffee is the greatest influence that can be found on water outflow. Thus, it was calculated (Equation 18-21):

$X_{c p}=\frac{\text { average thickness of exocarp }+ \text { a portion of mesocarp }}{\text { averagethickness of natural coffee }}$

$X_{m}=\frac{\text { average thickness of mesocarp }}{\text { average thickness of natural coffee }}$

$X_{p}=\frac{\text { average thickness of endocarp }}{\text { average thickness of natural coffee }}$

$X_{g}=\frac{\text { average thickness of endosperm }}{\text { average thickness of natural coffee }}$ 
The correction coefficients (A, B, C and D) of the proposed model were obtained by the STATISTIC $5.0^{\circledR}$ (Statsoft, 1995) software, performing nonlinear regression analysis by the Gauss-Newton method.

Variations in the physical properties of coffee fruits during drying are relevant characteristics in the optimization of industrial processes and in the development of new projects and equipment used in postharvest operations.

The volumetric contraction of the coffee and the separate coffee parts samples was determined by digital caliper measurements of the dimensions at the beginning, during and at the end of drying. With these measurements, it was possible to estimate and equate the volumetric contraction, depending on the water content and different drying air conditions, to calculate the resistance coefficient parameters.

\section{RESULTS AND DISCUSSION}

In order to calculate the resistance coefficient of coffee and its parts, the following values of diffusion coefficients (Equation 13 - Table 1) and specific area (Equations 14, 15 and 16 - Table 2) were considered. The calculation of the diffusion coefficient to assist in the evaluation and comparison of drying speeds, since each tissue and endosperm has different shapes and sizes, such as a change in the type of product, as well as the drying condition, can interfere in the process thermodynamic drying.

Table 1: Diffusion coefficient values $(D(m))$ for the four relative humidity studied.

\begin{tabular}{cc}
\hline TREATMENTS & $\mathrm{D}(\mathrm{m})\left(\mathrm{m}^{2} . \mathrm{s}^{-1}\right)$ \\
\hline Natural & $8.44939 \mathrm{E}-11$ \\
Pulped Natural & $6.78055 \mathrm{E}-11$ \\
Exocarp + a portion of mesocarp & $1.24394 \mathrm{E}-15$ \\
Mesocarp & $5.53693 \mathrm{E}-14$ \\
Endocarp & $4.12823 \mathrm{E}-15$ \\
Endosperm & $1.62634 \mathrm{E}-10$ \\
\hline
\end{tabular}

Because the pericarp tissues and endosperm were dried in a compartmentalized way, the thickness directly influenced the water outflow, because with the increase of the thickness the barriers for water migration from the interior to the exterior of the product are increased. Therefore, it was necessary to calculate the influence of each part of the coffee on the relative humidity used in this work.

Table 2: Values of the specific area $(\mathrm{Y})$ of natural, shelled coffee and of the parts that structure the coffee fruit.

\begin{tabular}{|c|c|c|c|}
\hline TREATMENTS & HR $(\%)$ & $\mathrm{a}_{\mathrm{w}}($ adimensional $)$ & $\gamma\left(\mathrm{m}^{2}\right)$ \\
\hline \multirow{4}{*}{ Natural } & 10.0 & 0.0762 & 0.000330 \\
\hline & 17.5 & 0.0969 & 0.000348 \\
\hline & 25.0 & 0.1053 & 0.000371 \\
\hline & 32.5 & 0.1326 & 0.000325 \\
\hline \multirow{4}{*}{ Pulped natural } & 10.0 & 0.0396 & 0.000184 \\
\hline & 17.5 & 0.0671 & 0.000159 \\
\hline & 25.0 & 0.0671 & 0.000190 \\
\hline & 32.5 & 0.0908 & 0.000166 \\
\hline \multirow{4}{*}{$\begin{array}{l}\text { Exocarp }+ \text { a portion of } \\
\text { mesocarp }\end{array}$} & 10.0 & 0.0839 & $8.25 \mathrm{E}-05$ \\
\hline & 17.5 & 0.1336 & $8.69 \mathrm{E}-05$ \\
\hline & 25.0 & 0.1510 & $9.27 \mathrm{E}-05$ \\
\hline & 32.5 & 0.1665 & $8.12 \mathrm{E}-05$ \\
\hline \multirow{4}{*}{ Mesocarp } & 10.0 & 0.1298 & 0.072223 \\
\hline & 17.5 & 0.1827 & 0.075451 \\
\hline & 25.0 & 0.1827 & 0.074414 \\
\hline & 32.5 & 0.2222 & 0.074210 \\
\hline \multirow{4}{*}{ Endocarp } & 10.0 & 0.0342 & $2.80 \mathrm{E}-05$ \\
\hline & 17.5 & 0.0717 & $3.29 \mathrm{E}-05$ \\
\hline & 25.0 & 0.0826 & $3.42 \mathrm{E}-05$ \\
\hline & 32.5 & 0.0797 & $2.91 \mathrm{E}-05$ \\
\hline \multirow{4}{*}{ Endosperm } & 10.0 & 0.0396 & 0.000112 \\
\hline & 17.5 & 0.0979 & 0.000132 \\
\hline & 25.0 & 0.0979 & 0.000137 \\
\hline & 32.5 & 0.1955 & 0.000116 \\
\hline
\end{tabular}

Considering that the total resistance is equivalent to the resistance of natural coffee, the proposed model, for the water resistance, described in equation 17 , for each relative humidity studied, the influences of the average thickness of each part of the coffee were calculated (Equations 18-21). The values were determined (Table 3):

Table 3: Values of the influence of the thickness of each part of the coffee fruit (decimal).

\begin{tabular}{ccccc}
\hline \multirow{2}{*}{$\begin{array}{c}\text { Parts that structure the } \\
\text { coffee fruit }\end{array}$} & 10.0 & 17.5 & HR (\%) & 32.5 \\
\cline { 2 - 5 } & 0.125445253 & 0.115145467 & 0.137351539 & 0.136862783 \\
$\mathrm{X}_{\mathrm{cp}}$ & 0.304758796 & 0.288370308 & 0.224060758 & 0.226081216 \\
$\mathrm{X}_{\mathrm{m}}$ & 0.017480634 & 0.025884701 & 0.041480165 & 0.041718997 \\
$\mathrm{X}_{\mathrm{p}}$ & 0.552315317 & 0.570599524 & 0.597107538 & 0.595337004 \\
$\mathrm{X}_{\mathrm{g}}$ & & & & \\
\hline
\end{tabular}


Each pericarp tissue and endosperm have different chemical compositions and anatomy, when it is subjected to analyzes separately, the behavior tends to be different, requiring comparative evaluation. In other words, natural coffee has all the pericarp tissue and endosperm, so it was used as total resistance to calculate the resistance of each part separately.

The coefficient of resistance of the natural, pulped natural coffee and each part of the fruit was calculated by Equation 12. Table 4 shows the resistances found according to water activity:

Table 4: Resistance coefficient values $\left(\mathrm{m}^{2} . \mathrm{s} . \mathrm{kg}^{-1}\right)$ for natural, pulped natural coffee and for each part of the fruit, as a function of water activity.

\begin{tabular}{|c|c|c|c|}
\hline TREATMENTS & HR (\%) & $\mathrm{a}_{\mathrm{w}}($ dimensionless $)$ & $\eta\left(\mathrm{m}^{2} . \mathrm{s} \cdot \mathrm{kg}^{-1}\right)$ \\
\hline \multirow{4}{*}{ Natural } & 10.0 & 0.0762 & $7.66 \mathrm{E}-13$ \\
\hline & 17.5 & 0.0969 & $6.17 \mathrm{E}-13$ \\
\hline & 25.0 & 0.1053 & $6.00 \mathrm{E}-13$ \\
\hline & 32.5 & 0.1326 & 4.74E-13 \\
\hline \multirow{4}{*}{ Pulped natural } & 10.0 & 0.0396 & $1.28 \mathrm{E}-15$ \\
\hline & 17.5 & 0.0671 & $8.12 \mathrm{E}-16$ \\
\hline & 25.0 & 0.0671 & 7.19E-16 \\
\hline & 32.5 & 0.0908 & $5.11 \mathrm{E}-16$ \\
\hline \multirow{4}{*}{$\begin{array}{l}\text { Exocarp }+ \\
\text { a portion of } \\
\text { mesocarp }\end{array}$} & 10.0 & 0.0839 & $1.75 \mathrm{E}-21$ \\
\hline & 17.5 & 0.1336 & $1.27 \mathrm{E}-21$ \\
\hline & 25.0 & 0.1510 & $1.18 \mathrm{E}-21$ \\
\hline & 32.5 & 0.1665 & $1.03 \mathrm{E}-21$ \\
\hline \multirow{4}{*}{ Mesocarp } & 10.0 & 0.1298 & $5.61 \mathrm{E}-17$ \\
\hline & 17.5 & 0.1827 & 4.76E-17 \\
\hline & 25.0 & 0.1827 & $4.64 \mathrm{E}-17$ \\
\hline & 32.5 & 0.2222 & $4.28 \mathrm{E}-17$ \\
\hline \multirow{4}{*}{ Endocarp } & 10.0 & 0.0342 & 4.08E-20 \\
\hline & 17.5 & 0.0717 & $1.59 \mathrm{E}-20$ \\
\hline & 25.0 & 0.0826 & $9.54 \mathrm{E}-21$ \\
\hline & 32.5 & 0.0797 & $8.30 \mathrm{E}-21$ \\
\hline \multirow{4}{*}{ Endosperm } & 10.0 & 0.0396 & $1.33 \mathrm{E}-15$ \\
\hline & 17.5 & 0.0979 & $6.30 \mathrm{E}-16$ \\
\hline & 25.0 & 0.0979 & $6.02 \mathrm{E}-16$ \\
\hline & 32.5 & 0.1955 & $3.35 \mathrm{E}-16$ \\
\hline
\end{tabular}

It can be observed, in Table 4, that regardless of the coffee fruit part, or being natural or pulped natural, the lowest resistance to water outflow is obtained in the highest water activity, for the four relative humidity studied.

According to the results presented in Tables 4 and 5, it is possible to observe that regardless of the relative humidity studied, the endosperm is the one with the greatest thickness and consequently the greatest resistance to dehydration. In addition to anatomy, the endosperm is mainly composed of cellulose and hemicellulose, these compounds have hygroscopic characteristics, that is, they absorb water easily, the predominance of one component or another, given the greater or lesser affinity of water with each of these compounds influences at the water outlet (Borém et al., 2013b).

This is because, in higher water activity, free water availability is higher when compared to lower water activity, in other words, this gradient difference makes it easier for water outflow.

There are no studies in the literature that relate the anatomical components of coffee with resistance to dehydration. However, it can be inferred that the values found are due to the difference in the vapor pressure gradient, since the higher the relative humidity of the drying environment, the lower the vapor pressure gradient between the grain and the drying air, which gave less resistance to dehydration.

Table 4 shows that the consideration of natural coffee as total resistance is satisfactory, then the resistance value is higher than the pulped natural coffee, pericarp tissues and endosperm.

The lowest resistance is observed for the exocarp + part of the mesocarp. This value can be explained by the anatomy of the exocarp, then this tissue is formed by a layer of compact, polygonal and parenchymal cells, that is, it is extremely thin, which facilitates the outflow of water (Borém et al., 2014a).

To perform the mathematical modeling of the data, in order to correct the fact that the parts were already separated, it was necessary to create correction coefficients for each part of the coffee fruit.

From the determination of these values, it was possible to determine the correction coefficients of the coffee fruit parts. These parameters were experimentally calculated by computer simulation in STATISTIC 5.0 ${ }^{\circledR}$ software. The values for each parameter were obtained (Table 5):

Table 5: Parameters of the proposed model to analyze the resistance of each part of the coffee fruit, coefficient of determination (\%), estimate standard deviation (decimal) and mean relative error (\%).

\begin{tabular}{cccccccc}
\hline \multirow{2}{*}{ MODEL } & \multicolumn{7}{c}{ Parameter } \\
\cline { 2 - 9 } & A & B & C & D & $\mathrm{R}^{2}$ & SE & P \\
\hline Proposed model & $2.676592 \mathrm{E}+09$ & 18317.91 & 105729.9 & -155.143 & 92.84 & 0.031 & 1.105 \\
\hline
\end{tabular}


Table 5 shows that the model used to determine the parameters of the coefficient of resistance presented satisfactory coefficient of determination $\left(\mathrm{R}^{2}>90 \%\right)$. Regarding the average relative error, the value found by the model was $1.105 \%$, indicating a $\mathrm{P}<10 \%$; The value found indicates that the model is adequate to represent the phenomenon studied, as well as the standard deviation of the mean (SE) presents satisfactory values, with SE $<0.05$ (Madamba; Driscoll; Buckle, 1996; Mohapatra; Rao, 2005).

The data observed in Tables 1 - 4, it was possible to calculate and analyze the resistance variation for each pericarp tissue and endosperm, determining that the values of thickness and effective diffusion interfered with the speed of the water outlet. The drying conditions, due to differences in relative humidity, made the migration of humidity from the inside of the product to the outside different, being that, regardless of the treatment, the lower resistance to water output is obtained in the greater water activity.

In the figures below (Figure 2-7), it is possible to observe the differences of the resistances that each part of the coffee fruit in the water outlet according to the water activity.

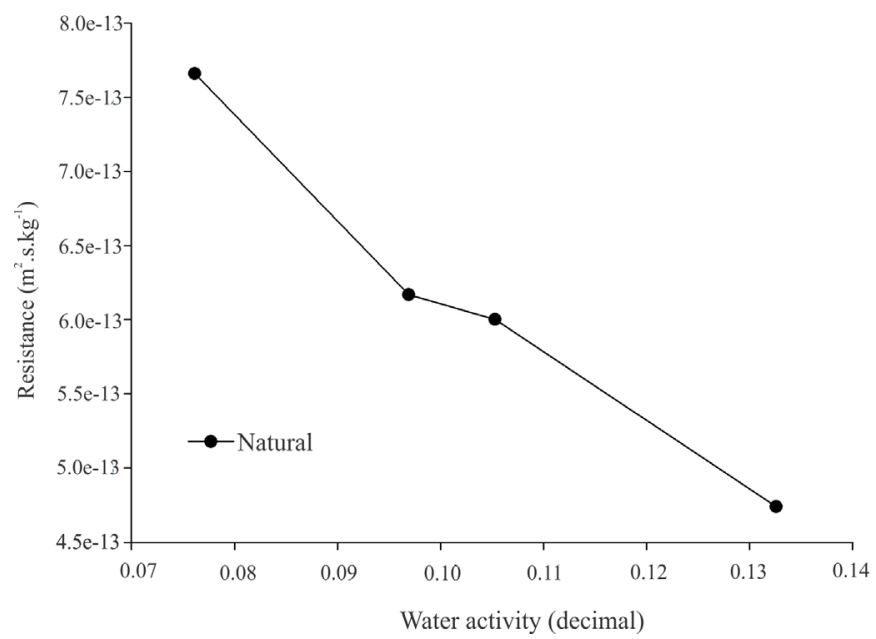

Figure 2: Variation of natural coffee resistance in relation to water activity.

Table 6 shows the corrected values of the pericarp tissues and endosperm resistance of coffee fruit according to the parameters found in Statistic $5.0^{\circledR}$.

The parameters found by the proposed model correct the fact that the coffee fruit tissues and endosperm are separated at the time of drying for each relative humidity studied, then the sum approximates the result found for natural coffee, considered as total resistance to model validation.

According to Table 6 , it is found that natural coffee can be considered as total resistance, then it has the highest resistance value, as it is composed of all the anatomical parts of the fruits. The results corroborate the values found for the coefficient of determination $\left(\mathrm{R}^{2}\right)$, estimate standard deviation $(\mathrm{SE})$ and mean relative error $(\mathrm{P})$.

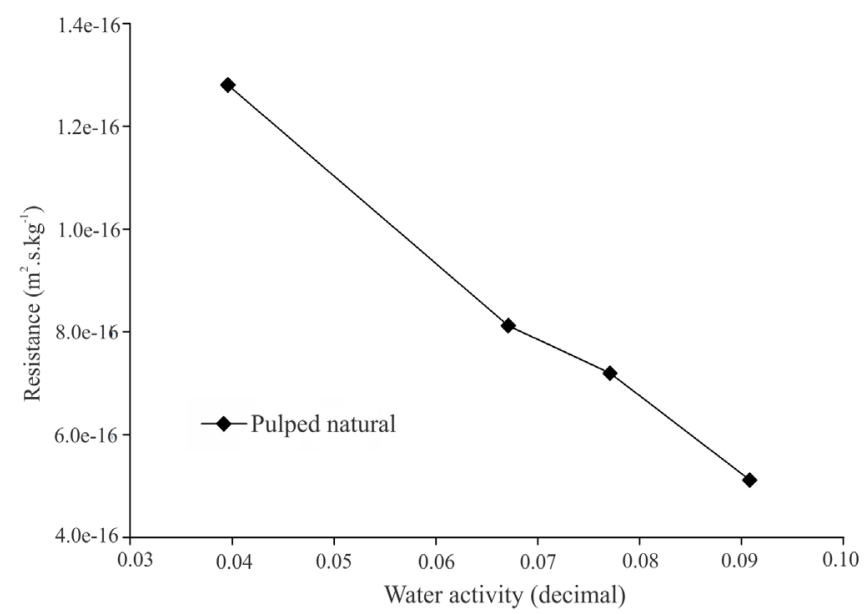

Figure 3: Variation of pulped natural coffee resistance in relation to water activity.

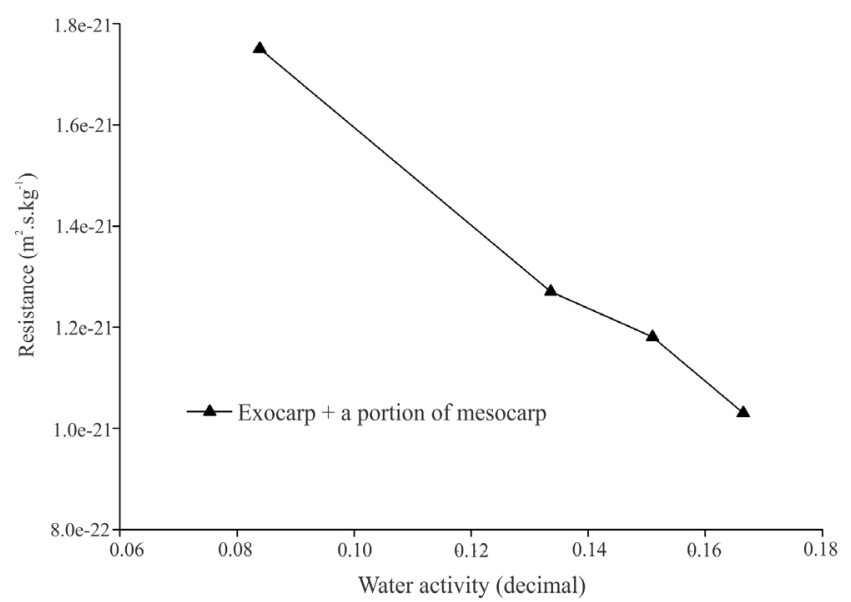

Figure 4: Variation of exocarp + a portion of mesocarp resistance in relation to water activity.

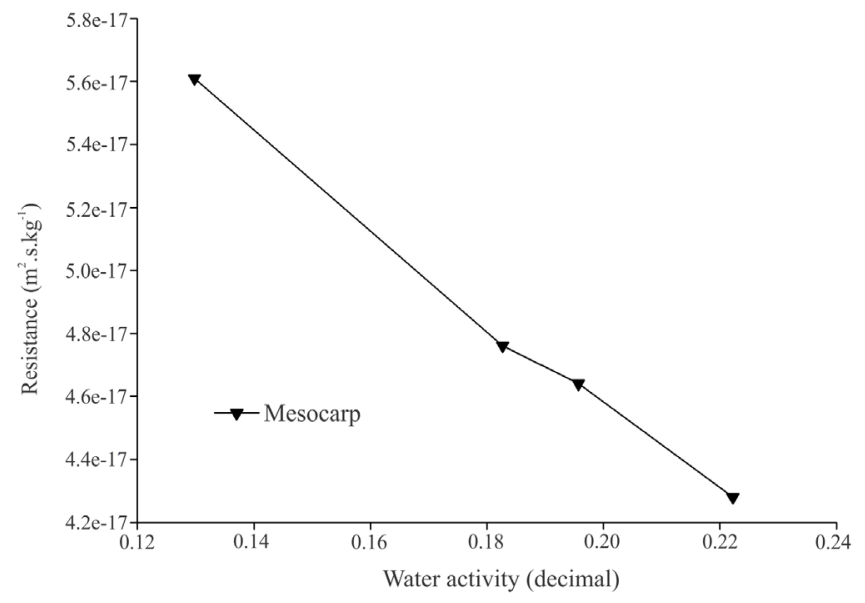

Figure 5: Variation of mesocarp resistance in relation to water activity. 


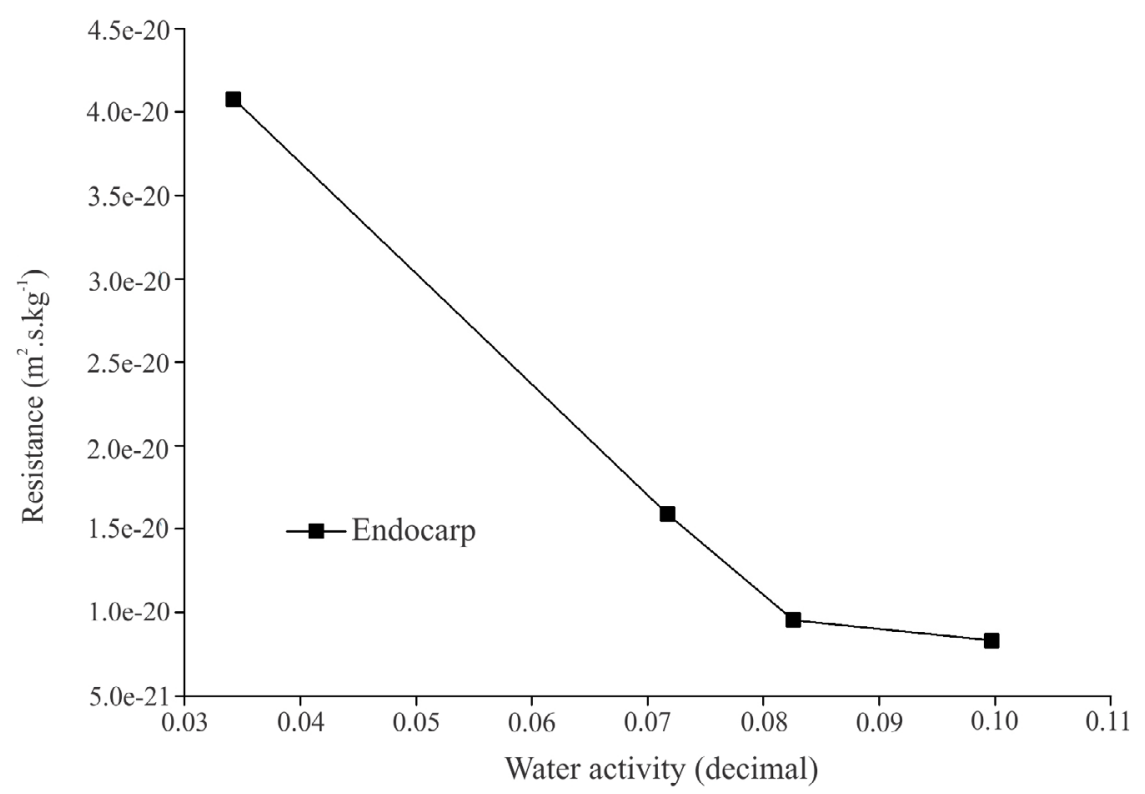

Figure 6: Variation of endocarp resistance in relation to water activity.

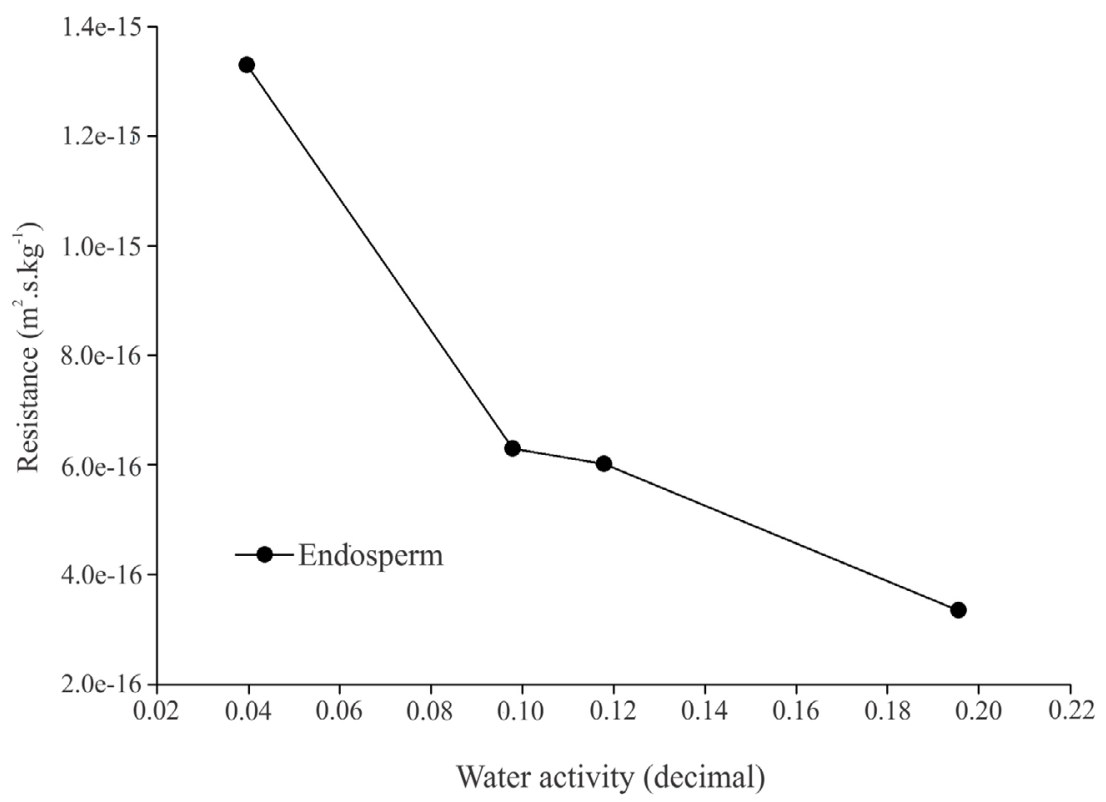

Figure 7: Variation of endosperm resistance in relation to water activity.

Table 6: Sum of the resistances of each part of the coffee fruit considering average thickness and correction factor compared to the total resistance (natural coffee).

\begin{tabular}{|c|c|c|c|c|}
\hline \multirow{2}{*}{ TREATMENTS } & \multicolumn{4}{|c|}{$\operatorname{HR}(\%)$} \\
\hline & 10.0 & 17.5 & 25.0 & 32.5 \\
\hline Natural & $7.65657 \mathrm{E}-13$ & 6.17111E-13 & 6.00363E-13 & 4.74079E-13 \\
\hline Exocarp + a portion of mesocarp & $5.89178 \mathrm{E}-13$ & $3.90698 \mathrm{E}-13$ & $3.57954 \mathrm{E}-13$ & $3.11653 \mathrm{E}-13$ \\
\hline Mesocarp & $3.12997 \mathrm{E}-13$ & $2.51412 \mathrm{E}-13$ & $2.10859 \mathrm{E}-13$ & $1.95971 \mathrm{E}-13$ \\
\hline Endocarp & $7.53844 \mathrm{E}-17$ & 4.34389E-17 & $4.18466 \mathrm{E}-17$ & 3.65964E-17 \\
\hline Endosperm & $-1.13712 \mathrm{E}-13$ & $-5.57508 \mathrm{E}-14$ & $-5.57261 \mathrm{E}-14$ & $-3.0981 \mathrm{E}-14$ \\
\hline Sum of the parts that structure the coffee fruit & $7.88538 E-13$ & 5.86403E-13 & 5.13129E-13 & $4.7668 \mathrm{E}-13$ \\
\hline
\end{tabular}




\section{CONCLUSIONS}

- Natural coffee has the highest resistance, $7.65657 .10^{-13} ; 6.17111 .10^{-13} ; 6.4715 .10^{-13} ; 4.74079 .10^{-13}$ $\mathrm{m}^{2} . \mathrm{s} \cdot \mathrm{kg}^{-1}$, at the relative humidity of $10.0 ; 17.5 ; 25.0$ and $32.5 \%$, respectively.

- Natural, pulped natural coffee, pericarp tissues and endosperm presented the highest resistance value in the lowest water activity.

- Each part of the coffee gives a different resistance to the water outflow, being the highest value found for the endosperm, followed by the mesocarp, endocarp and exocarp + a portion of the mesocarp, successively.

\section{ACKNOWLEDGEMENTS}

The authors are grateful to the Brazilian Federal Agency for the Support and Evaluation of Graduate Education (CAPES), the Minas Gerais Research Foundation (FAPEMIG), the National Council for Scientific and Technological Development (CNPq) and the Instituto Nacional de Ciência e Tecnologia do Café (National Institute for Coffee Science and Technology; INCT-CAFÉ).

\section{REFERENCES}

BABBITT, J. D. On the diffusion of adsorbed gases through solids. Canadian Journal of Physics, 29:437-446, 1950.

BECKER, H. A.; SALLANS, H. R. A theoretical study of the mechanism of moisture diffusion in wheat. Cereal Chemistry, 34:395-409, 1957.

BORÉM, F. M.; GARCIA-SALVA, T. J.; SILVA, E. A. A. da. Anatomy and chemical composition of the coffee fruit and seed. In: BORÉM, F. M. (Ed.). Handbook of coffee post-harvest technology. Norcross: Gin, 2014a. p.1-10.

BORÉM, F. M.; ISQUIERDO, E. P.; TAVEIRA, J. H. S. Coffee processing. In: BORÉM, F. M. (Ed.). Handbook of coffee post-harvest technology. Norcross: Gin, $2014 \mathrm{~b}$. 49-68p.

BORÉM, F. M.; REINATO, C. H. R.; ANDRADE, E. T. Secagem do café. In: BORÉM, F. M. (Ed.). Pós-colheita do café. Lavras: Ed. UFLA, 2008. p.205-240.

COMPANHIA NACIONAL DE ABASTECIMENTO CONAB. Acompanhamento da safra brasileira café, safra 2019. Available in: $<$ http://www.conab.gov.br>. Access in: February, 20, 2019.

COSTA, L. M. et al. Coeficiente de difusão efetivo e modelagem matemática da secagem de sementes de crambe. Revista Brasileira de Engenharia Agrícola e Ambiental, 15(10):1089-1096, 2011.

DIAS, C. A. et al. Sorption isotherms and isosteric heat of pericarp and endosperm tissues of arabica coffee fruit. Revista Brasileira de Engenharia Agrícola, 40(1):7889, 2020.

FORTES, M. et al. Modelagem de um condicionador de ar de alta precisão para uso em processamento agrícola. Engenharia Agrícola, 26(2):578-589, 2006.

MADAMBA, P. S.; DRISCOLL, R. H.; BUCKLE, K. A. Thin-layer drying characteristics of garlic slices. Journal of Food Engineering, 29(1):75-97, 1996.

MOHAPATRA, D.; RAO, P. S. A thin layer drying model of parboiled wheat. Journal of Food Engineering, 66(4):513-518, 2005.

OLIVEIRA, R. A.; OLIVEIRA, W. P.; PARK, K. J. Determinação da difusividade efetiva de raiz de chicória. Engenharia Agrícola, 26(1):181-189, 2006.

PABIS, S.; JAYAS, D. S.; CENKOWSKI, S. Grain drying: theory and pratice. New York: J. Wiley, 1998. 303p.

RESIO, C. A.; AGUERRE, R. J.; SUAREZ, C. The drying of amanthus grain: mathematical modeling and simulation. Brazilian Journal of Chemical Engineering, 22(2):303309, 2005.

SCHÄR, W.; RUËGG, M. The Evaluation of GAB Constants from Water Sorption Data. Lebensmittel-Wissenschaft und-Technologie, 18:225-229, 1985.

SMITH, J. M.; VAN NESS, H. C.; ABBOTT, M. M. Introducción a la termodinámica en ingeniería química. 5. ed. México: McGraw Hill, 1997. 616p.

STATSOFT. Statistica: data analysis software system. Version 5.0. 1995. Available in: <http://www.statsoft. com>. Access in: June, 20, 2015.

TOCI, A. T. et al. Changes in triacylglycerols and free fatty acids composition during storage of roasted coffee. LWT - Food Science and Technology, 50(2):581-590, 2013. 